\title{
The impact of paramilitary violence against a heroin-user community in Northern Ireland: A qualitative analysis
}

\author{
Kathryn Higgins ${ }^{*}$, Rosemary Kilpatrick ${ }^{1}$ \\ Institute of Childcare Research, Queens University of Belfast, 5 a Lennoxvale, Belfast BT9 5BY, UK
}

Received 1 September 2004; received in revised form 8 June 2005; accepted 28 June 2005

\begin{abstract}
Over the past decade, Northern Ireland has witnessed the cessation of conflict and the emergence of the ongoing peace process. It is now dealing with new patterns of crime and with social problems either ignored or suppressed during the years of the so-called 'Troubles'. A key example is heroin and injecting drug use. Systematic beating, exiling and torture by paramilitaries remain pervasive in many communities. Drawing on data from a qualitative study examining the emergence of the heroin scene in Ballymena, this paper presents findings that illustrate the impact of paramilitary violence on a heroin-using community. The paper describes, both from the perspective of the heroin users and the professionals seeking to help them, the violence and intimidation perpetrated by the paramilitants. The impact this rough justice has on their day to day lives is explored, as well as the difficulties it presents in influencing their decisions to utilise services such as harm reduction initiatives. The paper provides context by summarising available evidence on the extent of heroin use in Northern Ireland and presenting a brief account of current Northern Ireland drug policy. The historical relationship between paramilitary groups and communities is also briefly outlined. By way of conclusion, the paper discusses the relationship between wider societal transformation in Northern Ireland and drug-use patterns and outlines how heroin users might be assisted in dealing with the compounded nature of the challenges facing them as a result of the paramilitary threat.
\end{abstract}

(C) 2005 Elsevier B.V. All rights reserved.

Keywords: Heroin users; Paramilitary violence; Drug policy; Treatment; Post-conflict

\section{Introduction}

The arrival of the paramilitary cease-fires in 1994 and the often-faltering 'Peace Process' has brought Northern Ireland along its transition toward a non-violent society. The main political parties endorsed the principles of non-violence and democracy contained in the Belfast Agreement, and a concomitant decrease in police and military security operations ensued. This was followed by the release of former political prisoners. The extant peace has, however, been labelled 'imperfect' and one in which 'acceptable levels' of violence persist. Systematic beating, exiling and torture by paramilitaries are ongoing (Knox, 2002). In addition to resolving

\footnotetext{
* Corresponding author. Tel.: +44 2890 974608; fax: +44 2890687416.

E-mail addresses: k.m.higgins@qub.ac.uk (K. Higgins),

R.Kilpatrick@qub.ac.uk (R. Kilpatrick).

1 Tel.: +44 2890 975570; fax: +44 2890687416 .
}

the long-standing problems associated with the sectarian and divided nature of Northern Ireland culture, it has been suggested that a decrease in political violence has been accompanied by a growth in so-called 'normal' patterns of crime that were masked or indeed suppressed by the 'Troubles' (e.g., Independent Commission on Policing in Northern Ireland, 1999). A key example is heroin and injecting drug use, which did not emerge as a problem in Northern Ireland until the mid-1990s, coincidently or otherwise at the same time as the cease-fires.

Utilising data from a qualitative study examining the emergence of the heroin scene in Ballymena, Northern Ireland, this paper describes from both the perspective of the heroin user and professional stakeholders, the violence and intimidation perpetrated by the paramilitants on the heroin-user community. The impact of the violence on users' everyday lives is examined alongside its possible effect on service utilisation and treatment compliance. By way of context, the paper com- 
mences with a summary of the Northern Ireland heroin scene and briefly describes the relationship paramilitaries have with communities. Finally, the paper draws to a close with a number of hypotheses concerning the reasons why heroin use has escalated in this context and how users might be helped to deal with the compounded nature of the challenges facing them as a result of the paramilitary violence.

\section{The emergence of a heroin scene in Northern Ireland}

Historically, Northern Ireland has been regarded as a low drug use, low-crime country compared to its Northern European neighbours (Brewer, Lockhart, \& Rodgers, 1997; Mayhew \& van Dijk, 1997). There is no real evidence that suggests that heroin use was widespread during the 1970s and 1980s (McElrath, 2004). Limited acknowledgement of heroin use as a problem appeared to enter the Northern Ireland public domain in the mid-1990s coincidently or otherwise at the same time as the cease-fires occurred (Higgins, Percy, $\&$ McCrystal, 2004; McElrath, 2002). As can be seen from Table 1, notifications to the Northern Ireland Drug Addicts Index have increased substantially over recent years.

Those increases were not uniform across Northern Ireland. Instead, particular areas became heroin 'hotspots'. The city of Belfast being the capital and largest city in Northern Ireland has witnessed significant pockets of use (McElrath, 2002). However, a smaller town northeast of Belfast, Ballymena, Co. Antrim emerged as a major heroin market. Evidence from community workers detailing the extent of the problem was forthcoming from the mid-1990s and there were increasing media reports detailing the emerging problem of heroin use. By 1997 even the Addicts Index, a lagged indicator of use was evidencing significant notifications for the town and surrounding areas (Table 1).

In the year 2000, notifications from the Ballymena area, covered by the Homefirst Community Trust, constituted over half of those for the whole of Northern Ireland (Table 1). In 2002, McElrath conducted a systematic prevalence estimate using capture-recapture methodology. She concluded that regionally, there were between 695 and 1018 'problem heroin users'. Her study, although regional in its focus, highlighted that there were certain areas within Northern Ireland which indicated high levels of injecting use, one such area being Ballymena which she stated had a higher prevalence of injecting users than anywhere else (McElrath, 2002).

\section{Policy context}

Current Northern Ireland drug policy is embodied in 'The Drug Strategy for Northern Ireland 1999'. It embraces the main aims and objectives of the UK Government's drugs strategy, 'Tackling drugs to build a better Britain' first launched in 1998 subsequently updated in 2002. While the Northern Ireland strategy is largely complementary to those in place for other parts of the UK, it is presented as being more developmental in nature (Drugscope, 2000). Policy here has lagged behind that of the UK overall. The historically low prevalence of heroin use has meant that the outbreak of heroin use in Northern Ireland has occurred in areas with few treatment, harm reduction and information facilities for users. That said that evidence of increases in injecting had been forthcoming since at least 1996, yet Northern Ireland drug policy is only now, at the time of writing, permitting methadone maintenance or other substitute prescribing.

Furthermore, it is only since 2001 that needle exchange schemes have been operational in a number of sites in Northern Ireland. The full range of treatment modalities, so well evaluated across the UK and Europe, are not available to date in Northern Ireland. While the number of agencies dealing with drug use in Northern Ireland has burgeoned in recent years, they are still small in number relative to facilities across the UK. Policy and practice in Northern Ireland could have been considerably more expedient in responding to the evolving opiate problem.

\section{The paramilitary role in communities in Northern Ireland}

Despite the ongoing peace process, paramilitary violence pervades many communities where paramilitary groups have malign impact through their attempts to exercise control and to operate what amount to alternative justice systems (Cavanagh, 1997; Independent Monitoring Commission, 2004; Knox, 2002). Yet, the historic relationship between paramilitaries and the various communities in Northern Ireland is a complex one. Many communities have for some time not just tolerated but expected paramilitary input in the control of their area (Brewer et al., 1997; Dunn, Morgan, \& Dawson 2000). It has been argued that communal cohesion was caused by a lack of national state legitimacy and faith in the police by communities and that as a consequence

Table 1

Notifications to the Northern Ireland Drug Addicts Index 1994-2004 for all of Northern Ireland and for the Homefirst Community Trust by year

\begin{tabular}{|c|c|c|c|c|c|c|c|c|c|c|c|}
\hline & \multicolumn{11}{|l|}{ Year } \\
\hline & 1994 & 1995 & 1996 & 1997 & 1998 & 1999 & 2000 & 2001 & 2002 & 2003 & 2004 \\
\hline Northern Ireland total & 87 & 96 & 120 & 162 & 229 & 306 & 304 & 302 & 296 & 241 & 259 \\
\hline Homefirst Community Trust & 14 & 10 & 26 & 63 & 102 & 145 & 158 & 138 & 124 & 92 & 105 \\
\hline $\begin{array}{l}\text { Homefirst Community Trust as a } \\
\text { percentage of NI total }(\%)\end{array}$ & 16 & 10 & 22 & 39 & 45 & 47 & 52 & 46 & 42 & 38 & 41 \\
\hline
\end{tabular}

Source: Statistical Bulletin DAIRU 1/2005. 
paramilitary involvement in the social control of communities was demanded (Cavanagh, 1997; Dunn et al., 2000). However, this research also notes the fine line between acceptance and rejection of such groups by communities and goes on to state that administration of too much rough justice risks alienating or reducing the paramilitant support base. Research has also indicated a lessening of support for paramilitary involvement in some communities after the cease-fires (Dunn et al., 2000). Unfortunately, eliciting the views of the specific communities in which the research took place regarding the paramilitary violence against heroin users was beyond the scope of the present study.

\section{Methods}

This paper draws on findings from a qualitative study conducted in Ballymena, Northern Ireland between February 2001 and June 2002. In depth, interviews were undertaken with 31 respondents identified as being current injecting drug users in the research area. Inclusion criteria required that users had injected heroin in the past month and were under 30 years. All interviews with heroin users were conducted by the first author in the homes of the respondents, two local community centres or in semi-private locations such as in a discreet corner of a local hotel lobby bar. The sample was recruited through snowball sampling techniques (Erickson, 1979), as well as through a gatekeeper who was a youth worker in the area operating a temporary mobile needle exchange service. The researcher also accompanied this worker in his mobile needle exchange over a 6-week period. While the primary purpose of this was to assist in sample recruitment, there was also opportunity to observe needle exchange transactions and converse with users. Field notes were taken during or following these activities.

\section{Sample profile}

All respondents injected heroin as their drug of choice with the majority reporting daily injection $(n=25)$. The remainder injected at least three times per week. More than two-thirds $(n=21)$ reported sharing of injecting equipment on at least one occasion in the past 6 months. The mean age of the sample was 24.5 years (range 17-30.5 years). All but one respondent was White. Twenty-nine were from Northern Ireland while one was from England and one from Scotland. The sample was predominantly male $(n=22)$ and reasonably balanced in terms of experience versus no experience of treatment and support services. Just under two-thirds of the sample reported themselves to be unemployed, the remainder were either in full- or part-time employment or were full-time students. The demographic profile of the study is consistent with those provided by other research in that location (McElrath, 2002). Where permission was given, interviews were tape-recorded and then transcribed and analysed using the QSR NUDIST software package. Over half of the users did not grant per- mission for tape recording of the interview and stated that they would not participate further if tape recording were an essential requirement. One respondent asked the researcher to leave their home when the issue of tape recording was introduced and was lost to the study. When asked the reasons for their reticence, they stated that they feared voice recognition by the police or paramilitary groups. Previous research in Northern Ireland circumvented these concerns by taking very detailed field notes (McElrath, 2001). This method was adopted in the present study when tape recording was refused. Semi-structured interviews were also conducted with 15 professional stakeholders who were representative of agencies working in the field of drug use. These interviews were taperecorded, transcribed and analysed using QSR NUDIST.

\section{The research setting}

The research was conducted within Ballymena Borough Council Area located in the northeast of Northern Ireland. The overall profile of the area of Ballymena is not one that typically fits that for a location for a heroin outbreak. Heroin use has typically been studied as an urban phenomenon, usually associated with socio-economically deprived highly urbanised areas (e.g. Frisher, 1995; Parker, Bury, \& Egginton, 1998; Stimson \& Oppenheimer, 1982). Yet, the Ballymena Borough in which the study is based is non-urban. It has high employment growth with below-average unemployment and long-term unemployment rates. Noble (2001) conducted a study of multiple deprivations across Northern Ireland. The Ballymena area as a whole is one of the most affluent areas in Northern Ireland with a ranking of 552 out of 566 (with one being most deprived and 566 least deprived). However, some but not all of the wards in which the research was conducted represented pockets of multiple deprivation in an otherwise prosperous environment. Specifically, the wards of Ballykeel, Ballee and Dunclug, areas in which some of the sample were resident, ranked 55th, 64th and 163rd, respectively. It is acknowledged that the Borough of Ballymena has a higher population of injecting drug users than the Northern Ireland average (McElrath, 2002). As far back as 1999, research by McElrath (2001) noted that heroin users from Belfast reported that they travelled to Ballymena to buy heroin and for some Ballymena was their primary market.

\section{Findings-day-to-day impact of the paramilitaries in the lives of heroin users}

The extent and level of concern expressed by heroin users about the threat posed to them by paramilitaries was notable. Respondents stated that they were told they were being targeted specifically because they were using heroin. Issues raised by the heroin users concurred with comments made by professionals working in the area. The profile of the violence and intimidation reported by respondents was wide ranging. It included severe punishment style beatings, systematic intimidation of users in their homes, paint bombing 
(where homes were attacked with homemade bombs filled with paint), petrol bombing and in some cases exiling from estates where users lived. Many reported incidents relating directly to themselves $(n=18)$ while almost all $(n=27)$ noted some incident or event which had been perpetrated against a close friend or relative, and all were acutely aware of the problems presented by paramilitarism in the user community more generally. Evidence of injuries was at times apparent on respondents when interviews took place.

\section{Beatings}

Over a third $(n=11)$ of respondents reported that they had been directly targeted and beaten by paramilitaries as demonstrated in the incidents recounted below. The range of injuries cited was significant and resulted in hospitalisation for several of the users.

'... I have been nearly killed. They put me in intensive care for a fortnight, they thought I was a goner, they done it to loads of people I know it isn't just me'.

(002 male 23years)

Several other respondents reported similar stories.

'The paramilitaries, I hear they will, the police I mean will turn a blind eye [to users] but the paramilitaries are a different story and they are the ones who are doing all the damage. One night in January there, I was walking up the road home and they turned on me and beat the shit out of me. I went to casualty but they said it was just severe bruising and that I was very lucky because another person had been admitted the same night he was on the skeg [heroin] too and had been in a terrible way on life support and all'. (018 male 25 years)

Others users appeared to believe they had been fortunate to date and the beatings were almost viewed as an occupational hazard that came with being a drug user living in the area.

'I was beaten up by the UVF'ers [Ulster Volunteer force] twice, the last time wasn't so bad there was a couple of months back and I just had to go in and get $\mathrm{X}$ rayed and that, there wasn't much I needed fixed I had a broke nose but that is it, you take it that's the way it is'.

(O23 male 22 years)

Some respondents talked about the constant targeting of users like themselves and the feeling that they would continue to be under attack until the paramilitaries got a result.

'I was sort of got at one night but I ran like hell before they could get me and it felt like they shot at me like when I was running and that scared me shiteless. It is only a matter of time before they get me for real'.

(004 male 20 years)
'I pay attention now you know when I am out and about and I keep all that in mind when I am making plans to score you know, making sure I meet up the town where I know they aren't likely to spot me, they mark your card as it were'.

(005 male 23 years)

Finally, there was also one fatality reported by a user who claimed that his closest friend had died in hospital as a result of a severe beating by the paramilitaries.

'I am not so frightened as I come from a more mixed part of town but I know that in Harryville and all, it can be quite bad. My friend was killed when they give him such a doing [beating] last year died in hospital a couple of weeks after. I know lots of people who have been assaulted and left to die people who have had their homes damaged and all so yes it is a major problem'.

(012 male 29 years)

There were also many users who reported that they constantly feared being beaten although to date they had not been attacked.

'Users are really scared you know they live in fear. Touch wood I have been ok, till now but I am getting a bit worried to be honest, you know what these places are like everybody knows your business and I would be worried. Not only about the beating but the fact that my work, the woman and all would find out why'.

(001 male 25 years)

\section{Systematic intimidation}

A number of users also reported damage to their homes or homes of a family member $(n=9)$ in the form of petrol bombs and paint bombs. These are perceived as intimidation techniques often used to force users to vacate their homes and estates. There was a sense of outrage that nothing could be done and yet there appeared to be reticence on the part of users to report such incidents to the police.

'I am very fearful of paramilitaries they have thrown petrol bombs in our house, beaten up friends and then that man who came and held me at knife point here in my home. I know he was connected to the paramilitaries. But we are drug users what are the police doing to do to help us-nothing'.

(011 female 25 years)

'They've put people like me out of our homes, beat us up then up ruined homes with bombs they watch people like me going in and out of town, they watch everything'.

(024 male aged 24) 
In the case of female users who had children there was an unwillingness to come forward due to fears of exposure to social services.

'You are scared what else they might do and with the wanes [children] it doesn't bear thinking about. I didn't want to let on in case the social workers came sniffing round again'.

(014 female 25 years)

There was also a sense that the paramilitary groups knew how to play on the fears of the heroin community by utilising subtle and non-violent tactics while also having the capacity for direct vandalism and criminal activity.

'They put us out of our first flat they started by coming round at night say if I was on my own or even when we were both here and just standing at the gate then they would come and ring the doorbell maybe a couple of times during the night. Then they spray painted the whole front wall with skeghead and that ... by that stage my nerves were shot and we got re-housed to here it isn't half as nice, he [her partner] was all for putting up a fight but I just wanted out of there'.

(031 female 26 years)

There was evidence of a feeling of ambivalence about police help to the user community. As was demonstrated above, some users appeared to perceive that they had more to lose by reporting such incidences, especially when there were additional concerns regarding children. Furthermore, there appeared to be a perception that there was little the police could or would do to apprehend the perpetrators. For example, after a beating incident one user noted.

'Police were helpful enough but I think they know who does this but can't do much about it'.

(023 male 23 years)

Others were more critical of the police response.

'It's like you deserve it when you are a user it is like the police don't really see you as a victim it is like you had it coming to you'.

(022 male 23 years)

\section{Difficulties in service access and treatment adherence}

Significant proportions of heroin users are not in contact with treatment (Frischer, Hickman, Kraus, Mariani, \& Wiessing, 2001; McElrath, 2002). The various barriers to help seeking among injecting drug users have been well documented (National Institute on Drug Abuse, 2000). Often cited barriers range from a lack of readiness, stigma, distrust and lack of faith in the services on offer. There are also factors concerning psychiatric conditions and psychosocial instability. For female users there are the additional barriers
(Marsh, D'Aummo, \& Smith, 2000; McLellan et al., 1998). For example for drug-using mothers, there are fears of the loss of dependent children if they seek help for their drug use. Finally, the social stigma for female users is also greater than for their male counterparts (Powis, Griffiths, Gossop, \& Strang, 1996). Measures to reduce drug-related harm require active participation by the users, such as return and collection of injecting equipment at designated pharmacies or clinics. Moreover, compliance with any service generally requires attendance at specific times, normally in the working hours (if an outreach service is not in place). As is the case for many heroin users, the barriers outlined above are applicable to the users in the Ballymena area. However, for users in this location they have the added dimension of working to accommodate their fears concerning the paramilitaries. One example pertains to access to clean injecting equipment. One of the two needle exchange schemes in the town is based in a community pharmacy in the middle of an area known to be a paramilitary stronghold. Several of the users expressed major concern about accessing equipment from that location, which is of closest proximity to their home due to fears that it was under surveillance from the paramilitary group.

'This is quite a small nosy place like and then you have the added crap of the paramilitaries and Harryville [the estate] is politically dodgy you know. I know quite a few ones who are saying that they would be too scared to go there not because the police would be watching out for users but the paramilitaries will'.

(001 male 25 years)

The difficulties prompted some users to suggest that they would rather share equipment or use blunt needles than attempt access from this location.

'If it was going there or having a dig with my mates pin [needle] I think I would have to say nothing would drag me over there'.

(003 male 26 years)

There was also the difficulty caused by having to alter routine in an attempt to safeguard property and family from paramilitary threats, as demonstrated by the extracts below.

'I am feared of sleeping at night in case they come back, so I try to get some sleep during the day so that I am up at night to keep an eye. They paint bombed us the last time but you are scared what else they might do and with the wanes [children] ... then I am shattered and the wanes are late for school and I have missed another appointment and they think I don't want help'.

(032 female 28 years)

'I miss appointments here and there with the GP, and that even with the probation boy you know, which is while bad 
coz I fall asleep. I am so knackered I am convinced they will come back at night you see that is when they come'. (003 male 26 years)

\section{The implications of paramilitary violence against heroin users from the professional perspective}

As noted, part of the research study also included 15 depth interviews with professionals dealing with the heroin issue. Respondents included the Drug Strategy Coordinator for Northern Ireland often referred to as the 'Drug Czar', members of the local Community Addiction team, the local Drug and Alcohol Co-ordination team, and representatives from local statutory agencies such the youth service and the probation service as well as those from voluntary drug agencies who deal with heroin users. A member of the Police Service Northern Ireland drugs squad was also interviewed who had knowledge of the area. Respondents were from a range of disciplinary backgrounds.

Several of the professionals interviewed confirmed that paramilitary violence against the heroin-user community as an ongoing and pervasive problem as this extract from an interview with a local drug worker demonstrates.

'For those at the coalface dealing with users of heroin one of the major issues coming up time and time again and maybe more important in their minds than lots of stuff we would be going on about is the violence and intimidation against them [heroin users] from the paramilitaries. There is such a fear there are such a sense of injustice that nothing has been done'.

(Youth worker)

The scope of the violence and intimidation described concurred with that reported by heroin users interviewed for the study. This is typified in an extract from an interview with one respondent.

'So you talk to families who are being victimised because a cousin of theirs is a heroin user and the petrol bombs have come through the door. I asked [name removed] in Ballykeel II [a housing estate], to keep a community diary for a month to find out the amount of attacks. I was mainly asking to see how many community detox's, how many community OD's were happening because I was being told that OD's were not happening. But everyone else was telling me that people were OD'ing left, right and centre. And what come out was that yes, that was happening, but that there were more people being petrol-bombed and intimidated and those kind of things. Em, now I mean, it's never a thing that I've got into coz I'm not going to put my neck on the line but like I've raised the possibility of maybe moving the location of one of the needle exchanges. They [the heroin users] are scared, because needle exchange punters came in and two doors up I think you have the UVF headquarters'.

(Drug and Alcohol Co-ordinator)

Professionals reported having to deal with the consequences of heroin users who were being intimidated out of communities by, for example, acting as advocates for them to the Housing Executive for re-housing and problems associated with keeping appointments due to physical assaults.

'There would be some days [name removed] wouldn't show up to the session and then the phone call might come a few days later to say he had been got to [by the paramilitaries] a few nights before and what can you say it is frustrating for all of us, maybe he was close to getting a place in detox. our hands are just tied'.

(Probation Officer)

There were also problems reported in getting forums or events involving users organised. For example, one respondent talked about trying to facilitate a treatment user group to provide input into future services.

'We had to change the venue four times because of the fear of paramilitaries, they [the heroin users] feel they are being watched and all of them came in the end, so many of them had cuts and bruises on them from the beatings that they've got in the last two or three weeks so I don't blame them for being scared'.

(Youth Worker)

Heroin users are known to be a client group with difficulties and in many cases compliance with treatment or probationary conditions proves challenging within the context of their chaotic lifestyle. Those professionals interviewed for this study that sought to help those with addiction expressed extreme frustration at having to deal with yet another extraneous hurdle posed by the activities of the paramilitaries against their client group.

'it is always a bit fragile you know getting them to stay with you when there isn't much on offer in the first place but then they get beaten up again or they are frightened they are going to come back and put a petrol bomb through their ma's window and you just think how much more complicated can this get'.

(Addiction Counsellor)

\section{Discussion and conclusion}

Conflict such as that witnessed in Northern Ireland is not a private experience and the suffering it engenders is resolved in a social context. While currently striving to work through the long-standing issues associated with its sectarian culture, hitherto unobserved problems have emerged, heroin 
use being a key example. Increases in heroin and other drug use appear to be common in societies experiencing transition. Notable examples include South Africa (United Nations Office on Drugs and Crime, 2002), and post-communist Baltic States of Lithuania, Latvia and Estonia (ECMDDA, 2002).

A central question then is whether a common set of causal processes explain increases in drug use in transitional societies. Unfortunately, much more research is required before the construction and testing of such a hypothesis becomes a possibility. In particular, more complex theoretical and empirical models are required that provide greater definition of the relationship between the multiple macro social processes and trends in drug use, that permit the testing of competing hypotheses regarding the main drivers of changing drug use at the macro level (see Anderson, 1995). The concept of Social Capital (e.g., Bourdieu, 1985; Coleman, 1998; Putnam, 1995) has been utilised by researchers trying to conceptualise social change in societies undergoing change (e.g., Raiser, Haerpfer, Nowotny, \& Wallace, 2001). Scholars have hypothesised how the various types of social capital become reconfigured in times of transition. Further development of this conceptual framework may be of use in taking forward future research specifically related to heroin use.

Data available within Northern Ireland do not permit the type of analysis required to establish how the cessation of violence and the ongoing peace process has contributed to an increase in heroin use. However, many law enforcement and overall social and cultural changes are likely to be significant, for example, changes in employment patterns (Northern Ireland Statistical and Research Agency, 2001). The issues mooted as of most significance are the considerable reduction in both police and military surveillance and the reconfiguration of paramilitary organisations and the redeployment of their members. Also of note are the possible changes in community cohesion post-cease-fires.

Analysis of available statistics would suggest that the reduction in police and military surveillance across Northern Ireland and in border regions, in particular, might have contributed to a more favourable environment for major drug importation and distribution. (Police Service for Northern Ireland, 2002). Indeed evidence would suggest that certain paramilitary group 'members', principally those from loyalist paramilitaries and fringe republican organisations, have seized upon the changing environment and invested their efforts in drug distribution and dealing (McDowell, 2001; Silke, 2000). In a similar vein ethnographic research within other transitional societies has indicated that major growth in drug markets did not simply happen. Rather they were actively developed by organised drug trafficking groups (UNODC, 2002).

The structure of communities is often cited as having been of protective significance through out the troubles (Curran, 1988; McElrath, 2004). Community cohesiveness and strong informal social controls (with paramilitary involvement) were documented in many areas on Northern Ireland (Leonard, 1994). Scholars have even recorded how conflict can serve to enhance community bonds, and mediate against the development of mental health problems and by extension drug use (Summerfield, 2000). Furthermore, research has indicated that strong cohesiveness within a community can act as a buffer against the effects of deprivation and crime, again deemed risk factors for drug use (Kawachi, Kennedy, \& Wilkinson, 1999). A logical supposition then is that when conflict abates, changes occur in the configuration of those communities that somehow facilitate insidious permeation of social problems like drug use.

However, it is difficult to present such hypotheses without acknowledging that the control exerted may also be an example of markedly negative social capital as described by (Portes $\&$ Sensenbrenner, 1993). So, while achieving suppression of, for example drug use, the control exerted in the longer term is profoundly damaging to communities. The role played by the various paramilitary groups in the informal policing of communities may have abated post-cease-fires (Dunn et al., 2000). However, fearing a dwindling support base and sense of control it could be argued that some paramilitary groups are championing the cause of what they see as sources of social evil in their communities in an attempt to win back followers. The result is that heroin users have become demonised by paramilitaries in some communities. This demonisation has been documented elsewhere, albeit at a more general level (Bryan, Moran, Farrell, \& O'Brien, 2000; Finnigan, 1996; Peretti-Watel, 2003). However, more research is needed to examine what if any effect, all of these issues have had on the heroin scene.

\section{Compounded challenges for the Northern Ireland heroin user}

The relatively recent arrival of the heroin problem in Northern Ireland resulted in it occurring in a context where treatment, harm reduction and information facilities for users were under development. This situation is not unique to Northern Ireland and shares common features with other locations experiencing transition post-conflict, albeit in very differing circumstances. Heroin users in the location studied share many of the concerns of their peers living elsewhere in terms of stigma and service access. However, the stigma attached to being a heroin user may be even more pronounced in a society where there is considerable ignorance and intolerance of the heroin issue (Northern Ireland Public Attitude Survey, 1995). There is also a political connotation-in communities strongly affiliated with republicanism, attitudes are likely to be strong-as republican philosophy specifically linked drug use as being a direct threat to the success of the political cause (McElrath, 2004).

As noted earlier for the users in this location the welldocumented difficulties pertaining to service access are further complicated by the paramilitary threat. The importance of transport in relation to treatment attendance is often cited in 
the literature (Jacobson, 2004). In the area studied, although geographically small, respondents were observed taking taxis to treatment venues close to their homes for fear of walking through areas where paramilitaries were known to be active further adding to the cost of attendance. As noted earlier, use of the needle exchange was also reported as being influenced by fears of paramilitary surveillance.

The association between substance use and violence has been documented in treatment populations and it is acknowledged that the connection is complex (White, 1997; Boles $\&$ Miotto, 2003). While this substance use/violence nexus has been explored and theorised, it has in the main been restricted to intra user/dealer violence (e.g., Goldstein, 1985) or aimed at heroin dealers. In the South of Ireland, for example, a wave of anti-drug protests and community vigilantism against heroin dealers took place in the 1980s (Bennett, 1988) and 1990s (Peillon, 2002). The violence against heroin users described in this paper appears to be unique.

That the violence has a significant impact on the lives of heroin users in the research location is unquestionable. A central concern then is how can users of heroin continue to exist in this climate and what can be done to ameliorate their problems? Scholars have postulated that acceptance of violence per se was not uncommon in societies in which political institutions have emerged from war or conflict (Hayes \& McAllister, 2001). An important post-script to that theory is that such support is largely transitional. Once the principle of orderly transfer of political power following democratic elections becomes established, support for violence fades (Munger, 1975). It has been argued by some researchers and political figures that the government has until now been turning a blind eye to such violence in an attempt not to jeopardise the broader political process (Knox, 2002). However, that position no longer seems tenable given the recent publication of the (Independent Monitoring Commission Report, 2004) which highlights the necessity to move on from questions surrounding breaking the conditions of the cease-fires to a focus on the totality of illegal paramilitary activity, including organised crime, and the impact it has on individuals and communities in Northern Ireland.

So, it is likely that paramilitary violence in communities will be forced to abate as the peace process plays out and already there are signs of change. However, in the meantime policy and practice in Northern Ireland must remain ever cognizant of this unique legacy of the troubles. On a positive note evidence is emerging that treatment services have begun to respond in a pragmatic fashion to the problems of violence against users in the location studied. For example, a second site for substitute prescribing was opened in response to reports of users feeling intimidated when using the initial location. Other examples cited have included dialogue between a General Practitioner and a local paramilitary leader with the GP asking that the paramilitaries discontinue threats and intimidation against a user, which was causing distress to his patient who was stable on a substitute prescription (Flannagan, 2005).
Such creative and responsive solutions must be fully supported and extended to assist users facing the challenges presented by the paramilitary threat. Further development of outreach facilities is also imperative if users are intimidated when utilising existing services. Optimal use of needle exchange and treatment sites by heroin users is in the interest of wider public health. Northern Ireland to date has never had a public information campaign regarding heroin. While a level of stigma will always remain surrounding heroin use, a more educated public attitude and a greater understanding of the need for treatment and harm minimisation may in some way ameliorate the difficulties experienced by users in the longer term. That would, however, need to be accompanied by a withdrawal of public support for paramilitary violence in communities. Alternative models of social control must be supported and research into some of the restorative justice schemes in communities (Royal Ulster Constabulory, 2000) leaves some room for optimism in this regard.

In summation, Northern Ireland is only one of many regions throughout Europe experiencing new outbreaks of heroin use. Of particular note are the eastern European countries that have made the transition from communist control to developing democracies (European Monitoring Centre for Drugs and Drug Addiction, 2002). A key challenge, however, in these transitional societies is to build capacity so that emerging drug use patterns and hotspots can be identified and service responses targeted accordingly. A more rapid response is central to the success of such an endeavour, especially in a post-conflict situation where there are already damaged social and economic circumstances. The extensive, if fluctuating, interest in the Northern Ireland conflict from outside Ireland has more recently shifted towards comparative analysis of the Northern Ireland troubles to other societies emerging from ethnic conflicts (Mc Laughlin, 2001; Ó'Maoláin, 1993). The move towards comparative analysis is likely to continue in more detail. Further research exploring heroin use in Northern Ireland with other societies emerging from a cycle of religious or ethnic conflict could make a significant contribution to the international literature.

\section{References}

Anderson, T. (1995). Towards a preliminary macro theory of drug addiction. Deviant Behaviour, 16, 353-372.

Bennett, D. (1988). Are they always right? Investigation and proof in a citizen anti-heroin movement. In M. Tomlinson, T. Varley, \& C. McCullagh (Eds.), Whose Law and Order? Aspects of Crime and social control in Irish society (pp. 21-40). Belfast: The Sociological Association of Ireland.

Bourdieu, P. (1985). The forms of capital. In J. G. Richardson (Ed.), Handbook of theory and research for the sociology of education (pp. 241-258).

Boles, S., \& Miotto, K. (2003). Substance abuse and violence, a review of the literature. Aggression and Violent Behaviour, 8, 155174.

Brewer, J., Lockhart, B., \& Rodgers, P. (1997). Crime in Ireland 1945-95: 'Here be dragons'. Oxford, UK: Clarendon Press. 
Bryan, A., Moran, R., Farrell, E., \& O'Brien, M. (2000). Drug related knowledge, attitudes and beliefs in Ireland. Report of nation wide survey. Dublin: The Health Research Board.

Cavanagh, K. (1997). Interpretation of political violence in ethnically divided society. Terrorism and Political Violence, 9(3), 33-54.

Coleman, J. (1998). Social capital in the creation of human capital. American Journal of Sociology, 94, 95-121.

Curran, P. S. (1988). Psychiatric aspects of terrorist violence: Northern Ireland 1996-1987. British Journal of Psychiatry, 153, 470-475.

Drug and Alcohol Information and Research Unit (DAIRU). (2004). Statistics from the Northern Ireland Drug Addicts Index 2004. Statistical Bulletin 1/2005.

Drugscope. (2000). The UK drug situation-The UK report to the European Monitoring Centre for Drugs and Drug Addiction. London, UK: Drugscope.

Dunn, S., Morgan, V., \& Dawson, H. (2000). Attitudes to the criminal justice system, research report 12. Belfast: Northern Ireland Office.

Erickson, B. (1979). Some problems of inference from chain data. Sociological Methodology, 10, 276-302.

European Centre for Monitoring Drugs and Drug Addiction. (2002). Report on the Drugs Situation in Candidate CEEGs. Lisbon, Portugal: European Centre for Monitoring Drugs and Drug Addiction.

Finnigan, F. (1996). How non-heroin users perceive heroin users and how heroin users perceive themselves. Addiction Research, 4(1), 2532.

Flannagan, D. (2005). Snap shot of harm reduction in Northern Ireland. Conference paper presented at the 16th International Conference on the reduction of drug related harm. Belfast, Northern Ireland, 20-24th March 2005.

Frischer, M., Hickman, M., Kraus, L., Mariani, F., \& Wiessing, L. (2001). A comparison of different methods for estimating prevalence of problematic drug misuse in Great Britain. Addiction, 96, 1465-1476.

Frisher, M. (1995). Mapping the nature and extent of drug use in a community: The Glasgow experience. In J. Dickerson \& G. Stimson (Eds.), Drugs in the city. London: Royal Society of Health.

Goldstein, P. (1985). The drugs/violence nexus: A tripartite conceptual framework. Journal of Drug Issues, 15, 493-506.

Hayes, B., \& McAllister, I. (2001). Sowing dragon's teeth: Public support for political violence and paramilitarism in Northern Ireland. Political Studies, 49, 901-922.

Higgins, K., Percy, A., \& Mc Crystal, P. (2004). Secular trends in substance use: The conflict and young people in Northern Ireland. Journal of Social Issues, 6(3), 485-506.

Independent Monitoring Commission. (2004). First Report of the Independent Monitoring Commission. Belfast, UK: Her Majesty's Stationary Office.

Independent Commission on Policing in Northern Ireland. (1999). A new beginning: Policing in Northern Ireland. The report of the Independent Commission on Policing in Northern Ireland. Belfast, UK: Her Majesty's Stationary Office.

Jacobson, J. (2004). Place and attrition from substance abuse treatment. Journal of Drug Issues, 23-50.

Kawachi, I., Kennedy, B. P., \& Wilkinson, R. G. (1999). Crime: Social disorganization and relative deprivation. Social Science and Medicine, 48, 719-731.

Knox, C. (2002). 'See no evil, hear no evil'. Insidious paramilitary violence in Northern Ireland. British Journal of Criminology, 42, 164-185.

Leonard, M. (1994). Informal economic activity in Belfast. Aldershot: Avebury.

Marsh, J., D’Aunno, T., \& Smith, B. (2000). Increasing access and providing social services to improve drug use treatment for women with children. Addiction, 95, 1237-1247.

Mayhew, P., \& van Dijk, J. (1997). Crime and victimisation in eleven industrialised countries; key findings from the 1996 International Crime Victims Survey. The Hague, Netherlands: WODC.
McDowell, J. (2001). Godfathers: Inside Northern Ireland's drug racket. Dublin, Ireland: Gill and Macmillan.

McElrath, K. (2001). Heroin use in Northern Ireland. Belfast, UK: Department of Health, Social Services and Public Safety.

McElrath, K. (2002). The prevalence of problem heroin use in Northern Ireland. Belfast, UK: Department of Health, Social Services and Public Safety.

McElrath, K. (2004). Drug use and drug markets in the context of political conflict-The case of Northern Ireland. Addiction: Research and Theory, 12(6), 577-590.

Mc Laughlin, J. (2001). Re-imagining the nation-state the contested terrains of nation-building. London: Pluto Press.

McLellan, A., Hagan, T., Levine, M., Gold, F., Meyers, K., Bencivengo, M., et al. (1998). Supplemental social services improves outcomes in public addiction treatment. Addiction, 93, 1489-1499.

Munger, F. (1975). The legitimacy of opposition: The change in government in Ireland in 1932. Beverly Hills: Sage.

National Institute on Drug Abuse NIDA. (2000). Principles of drug addiction treatment: A research-based guide. NCADI publication 00-4180. Rockville: NIDA.

Noble, M. (2001). Measures of deprivation in Northern Ireland. Oxford: Social Disadvantage Research Unit.

Northern Ireland Attitudes Survey. (1995). http://www.ark.ac.uk/sol/ surveys/gem_social_att/nisa/1995/drugs.

NISRA (Northern Ireland Statistical and Research Agency). (2001). A profile of protestants and Roman Catholics in the Northern Ireland labour force. Belfast: Human Resource Research and Evaluation Branch.

Ó’Maoláin, C. (1993). Register of research on Northern Ireland. Coleraine: Centre for the Study of Conflict.

Parker, H., Bury, C., \& Egginton, R. (1998). New heroin outbreaks amongst young people in England and Wales. London, UK: Police Research Group.

Peillon, M. (2002). Exclusionary protests in urban Ireland City (Vol. 6 , No. 2).

Peretti-Watel, P. (2003). Heroin users as 'folk devils' and French public attitudes toward public health policy. International Journal of Drug Policy, 14, 321-329.

Police Service for Northern Ireland. (2002). Report of the Chief Constable. Belfast, UK: Author.

Portes, A., \& Sensenbrenner, J. (1993). Embeddedness and immigration: Notes on the determinants of economic action. American Journal of Sociology, 98, 1320-1350.

Powis, B., Griffiths, P., Gossop, M., \& Strang, J. (1996). The differences between male and female drug users: Community samples of heroin and cocaine users compared. Substance Use and Misuse, 31, 529-543.

Putnam, R. (1995). Bowling alone; Americas declining social capital. Journal of Democracy, 6(1), 65-78.

Raiser, M., Haerpfer, C., Nowotny, T., \& Wallace, C. Social capital in transition: A first look at the evidence (Working Paper no. 21). London: European Bank for Reconstruction and Development.

Royal Ulster Constabulory. (2000). Restorative conferencing. RUC pamphlets FP2564/99 and FP2563/99.

Silke, A. (2000). Drink drugs and rock n' roll: Financing loyalist terrorism in Northern Ireland-Part two. Studies in Conflict and Terrorism, 23, 107-127.

Summerfield, D. (2000). War and mental health: A brief overview. British Medical Journal, 321, 232-235.

Stimson, G., \& Oppenheimer, E. (1982). Heroin addiction. London: Tavistock.

United Nations Office on Drugs and Crime, Regional Office for South Africa, Country Profile on Drugs and Crime. (2002). Hatfield, South Africa: South Africa United Nations Office on Drugs and Crime.

White, H. (1997). Alcohol, illict drugs and violence. In D. Stoff, J. Brieling, \& J. Maser (Eds.), Handbook of antisocial behaviour (pp. 511-523). New York: Wiley. 